\begin{tabular}{l}
\hline POLITEIA \\
Politeia: Jurnal Ilmu Politik, 11 (1) (2019): 21-29 \\
ISSN 0216-9290 (Print), ISSN 2549-175X (Online) \\
Available online https:/ /jurnal.usu.ac.id/index.php/politeia \\
\hline
\end{tabular}

\title{
Youth Political Strategy in Political Contestation in 2014 Legislative Election
}

\author{
Febriza Rizky Adela1)*,Adil Arifin ${ }^{2)}$ \& Fernanda Putra Adela ${ }^{3)}$ \\ 1)Rural Area Development Planning Masters Program, University of Sumatera Utara, \\ Indonesia \\ 2)3)Political Science Study Program, Faculty of Social and Political Sciences University of \\ Sumatera Utara, Indonesia
}

Accepted December 2018, Approved December 2018, Published January 2019

\begin{abstract}
Abstrak
Tidak banyak pemuda yang aktif berpartisipasi atau mengambil bagian secara langsung di dalam kontestasi politik dan menjadi bagian yang berhasil memenangkan kontestasi tersebut. Dalam tulisan ini mengungkap strategi para pemuda untuk memenangi kontestasi politik dan menjadi anggota DPRD Kota Medan pada periode2014-2019, didalam ruang lingkup sistem yang demokratis dan berhasil menjadi salah satu bagian yang terpilih untuk mewakili masyarakat di dalam lembaga legislatif daerah. Tujuan tulisan ini adalah mendorong pembangunan politik yang lebih demokratis dalam peningkatan partisipasi kelompok muda untuk membangun daerahnya. Metodologi yang digunakan dalam tulisan ini adalah pendekatan kualitatif yang menghasilkan data deskriptif.
\end{abstract}

Kata Kunci: kontestasi politik, pemuda, pembangunan politik

\begin{abstract}
Not many young people actively participate in or take part directly in political contestation and become part of the success of winning the contest. In this paper, it reveals the strategies of the youth to win political contestation and become a member of the DPRD of Medan City for the period 20142019, within the scope of a democratic system and succeeded in becoming one of the elected parts to represent the community in the regional legislature. The purpose of this paper is to encourage more democratic political development in increasing the participation of young groups in developing their regions. The methodology used in this paper is a qualitative approach that produces descriptive data Password: political contestation, youth, political development
\end{abstract}

How to Cite: Adela, F.R, Arifin, A. \& Adela, F, P. (2018). Strategi Politik Pemuda di Dalam Kontestasi Politik pada Pemilu Legislatif Tahun 2014, Politeia: Jurnal Ilmu Politik, 11 (1) (2019): 21-29 


\section{INTRODUCTION}

Youth should participation in political development certainly create progress in realizing youth existence in the framework of fostering togetherness, where young people advance and unite. Contributions in seeing real development are highly expected, where the role of electibity and accountability, innovative and sustainable characterizes young people who are expected to have forward views and thoughts, to provide input or ideas in supporting development in the area.

Starting from the 1999 elections, Indonesia began to adopt a multi-party system. The existence of this multi-party system on the one hand has positive implications, which allows for a wide range of political accommodation for all elements of the Indonesian people, and youth is one of them. The considerable amount of open space in the context of political involvement should be understood as a great opportunity for youth to transform their role in political life in Indonesia.

In addition, the decentralization and regional autonomy regime implemented in Indonesia through Law Number 22 of 1999 and later replaced by Law number 32 of 2004 increasingly accommodates the wider community, especially young people to take a role in the leadership milestones at the central and regional levels through elections and post-conflict local elections. However, it is unfortunate, when a broad stream of democratization is not followed by wideranging political participation among young people to take a role in political constestation that allows youth to emerge as community leaders through existing political institutions.

The background of the lack of youth political participation is possible when referring to the theory of three elements of the legal system proposed by Friedman, namely the legal structure (structure of law), legal substance (substance of the law) and legal culture (legal culture). In substance, youth have been given a great opportunity to participate broadly in politics, this can be seen as legally formalistic from existing regulations. Structurally, existing institutions have taken the role of implementing and enforcing these rules. However, in legal culture, this involvement is constrained by the stigmatization of youth competency by the people who are considered still not qualified to become community leaders (Friedman, 2002: 8).

The dominance of the elderly in the political arena of the country has been made possible as well as a factor that "impedes" young people from appearing in political contestations. However, political life dominated by old figures is considered unable to bring significant changes to the quality of people's lives. This condition gave birth to issues regarding young leaders when the temperature of leadership succession began to heat up through the 2014 elections.

Without realizing it, the issue has directed the youth as a separate selling power for the community as a constituent to determine their choice in political contestation. This condition on the one hand can have positive implications for the involvement of the youth at large. But 
on the other hand, the existence of youth in the practical political realm is very vulnerable to the use of young people as the party's elite selling power to constituents, which inevitably allows young people in this matter to be used as a political engine in gaining votes without prioritizing a figure that is able to give a wind of change.

The involvement of youth in politics is meaningful because of the urgency of political regeneration, which should not merely regenerate the age of generations, but also in the form of thoughts, visions and views, the main values of leadership, democracy, equality and prosperity. These values are of course ideal for young people who are considered more energetic and innovative in looking at problems in society. Of course not also by giving up the role of the old group, so that it can be accommodated when the fundamental changes are made. This will have implications for the independence of the youth in conveying their ideas in the spirit of change and being able to synergize with the old group and position the existence of the old group as protectors.

\section{RESEARCH METHODOLOGY}

The approach in this study uses a qualitative approach (qualitativeresearch). A qualitative approach is defined as a research procedure that produces descriptive data in the form of written or oral words from people and observable behavior (Bogdan \& Taylor in Moleong, 2007: 4). This approach is directed at the background of these individuals holistically (intact). So in this case it is not permissible to isolate individuals or organizations into variables or hypotheses, but need to view them as part of a whole.

According to Nasution (2003: 5) qualitative research observes people in the environment, interacts with them and interprets their opinions about the world around. Qualitative research is also a study aimed at describing and analyzing phenomena, events, social activities, attitudes, beliefs, perceptions, thoughts of individuals as well as groups (Sukmadinata, 2005: 60). This qualitative research is specifically directed at the use of case study methods. Referring to the opinions of Lincoln and Guba (Lincoln \& Guba in Pujosuwarno, 1992: 34), a qualitative approach is in-depth and detailed research on everything related to the subject of research. Furthermore Sayekti Pujosuwarno (1986: 1) expressed the opinion of Moh. Surya and Djumhur who stated that case studies can be interpreted as a technique of studying someone individually in depth to help him get a good adjustment. According to Lincoln and Guba (Dedy Mulyana, 2004: 201) the use of case studies as a qualitative research method has several advantages, namely:

Case studies can present views of the subject under study;

The case study presents a comprehensive description that is similar to what the reader experiences throughout his life; Case studies are an effective means of showing the relationship between researchers and respondents; Case studies can provide the in-depth descriptions needed for assessment or transferability.

Basically research with a type of case study aims to find out something in depth. So in this study, researchers will use a case study method to reveal the 
political strategies used by Adlin Omar Yusri Tambunan and Ubaydillah in the 2014 legislative elections in Medan. This research is explorative which seeks to investigate a particular phenomenon by digging as much information as is considered to be related to the problem under study. The goal itself is to get to know and get new views about symptoms that are often able to formulate research problems more precisely or to be able to formulate research hypotheses which are then tested in further research. In this case, this exploratory research relates to methods or ways to explore and explore strategies used by a legislative candidate to win competition in the 2014 legislative elections (Sukandarrumidi, 2002: 103).

Therefore, the results of this study will describe the facts and various phenomena about the basis of the superiority and strategy of candidates in winning the competition or contestation in the 2014 legislative elections. Specifically in relation to the strategy established by Adlin Omar Yusri Tambunan and Ibnu Ubayd Dilla to win the legislative election in Medan City. The facts collected came from various observations and information from several communities, community leaders and certain individuals who were directly involved in the electoral process that took place.

Starting from the available materials, the author then compiled and determined and ensured that the cases that were the focus of the research were really found in the field so that it was feasible to continue in the research. In accordance with the purpose of this research is qualitative descriptive analysis, the data analysis is attempted to describe the full phenomenon and what is happening in the field.

\section{RESULTS AND DISCUSSION}

\section{Politicians \\ Political Strategy of Young}

The 2014 General Election has brought the contestation of candidates to think hard about careful planning in modifying candidates' campaigns which are manifested in the campaign strategy of the legislative candidates. The two young politicians who passed to become members of the Medan city legislature, namely Adlin Omar Yusri Tambunan and Ibnu Ubayd Dilla could be generalized to have a strategy to get support from the voters, namely:

Prepare for candidacy Managing information obtained from the field Organizing grassroots to maximize vote acquisition Identify issues and recruit successful and volunteer teams Voter mapping (election mapping) Campaign strategy by identifying battlefields Empower successful teams and campaign teams to secure the votes of each polling station, PPS, PPK, and KPUD.

Using party machines to continue guarding the votes obtained until the determination of elected candidates.

The political strategy carried out by Adlin Omar Yusri Tambunandan Ibn Ubayd Dilla was indeed structured and neat. This is evident from the start of the nomination stage up to the stage of securing the votes of the elected candidates. Political capital is conducted by Adlin Omar Yusri Tambunan by using his position as the District Leader (PK) of the Golkar Party to get number 1 in the 
List of Permanent Candidates. Then, family factors also determine in terms of vote acquisition Adlin Omar Yusri Tambunan.

The formation of a political strategy carried out by young politician Ibnu Ubaydillah is indeed not much different from the political strategy carried out by other politicians. But the most important thing here is that a young person signifies that the strategy of escorting and winning himself cannot be denied by utilizing young voters who in the 2014 General Election have delivered him to the Medan City DPRD building.

Ibnu Ubayd Dilla used the political strategy that was carried out from the party's internal sources. Of course, the combination that is obtained is that with the political capital that is owned, the social capital that has been built for a long time and also the economic capital that is the basis of the running of a winning machine makes him gain the trust to advance as a respected people's representative from the electoral area of 5 cities in Medan. Ibnu also used or utilized his extended family in increasing Ibn Ubayd's popolarity at the community level.

Social capital was used with Adlin Omar Yusri Tambunan's track record in organizing since he was a student, college and business world, so it is undoubtedly a long-established social base by Adlin Omar Yusri Tambunan. What also influenced social capital Adlin Omar Yusri Tambunan was a family factor of prominent bureaucrats and political figures. While Ibnu Ubayd Dilla did not have a qualified social base, Ibnu Ubayd Dilla was able to interact well with the people in his electoral district.
Then, the economic capital owned by Adlin Omar Yusri Tambunan was enough to deliver him a seat in the Medan City DPRD, although not as much as his seniors. This is because Adlin Omar Yusri Tambunan is a young politician who does not have a strong economic base, but because Adlin Omar Yusri Tambunan, a businessman, keeps himself alive in campaign funding up to the determination of election results. While Ibnu Ubayd Dilla, although it is not known the exact amount of funds owned, can be projected that Ibnu Ubayd Dilla has a large economic capital so that he is able to attract people to become his constituents seen from the domicile of Ibn Ubayd Dilla who does not live in the electoral

district.

Referring to the existing conditions, the use of an offensive strategy seems to be the choice of young politicians in their efforts to compete in the legislative elections. The defeat of the incumbent candidate in the Adlin Omar Yusri Tambunan electoral district could be a reference that Adlin Omar used an offensive strategy to obtain votes. Likewise in the five constituencies which were won by Ibnu Ubayd Dilla as candidate number 4 and the status of young politicians were able to win the legislative election contestation.

\section{Orientation Development for Young Politicians}

Winning the competition in the 2014 legislative elections in Medan City led two young politicians to become one of the people's representatives who sat in parliament. The ability of these two young politicians to be part of the regional government gives them access to power to play a role in decision making within the Medan city government. 
As part of the youth group that has been described about the values that exist within the youth, of course being a people's representative is not just becoming one of the officials in the city of Medan. Furthermore, the presence of these two young politicians as part of the regional government of the city of Medan should have a development plan that they had prepared before being elected as people's representatives.

Access of both to play an active role in development is certainly very possible because of the power of the institutions they have. The ability of these two young politicians to dynamize the development orientation they have planned is certainly very much expected according to the promises of the two young politicians during the campaign. Of course the development issues brought by the two young politicians are different, referring to the segmentation and demography of the electoral districts which are different from the two.

Becoming a people's representative is a process where Adlin Omar Yusri Tambunan was elected as a member of the Medan city legislature from the three electoral districts covering Medan Baru, Medan Barat, Medan Petisah and Helvetia sub-districts which are required to represent the community's interests in the electoral district. The three electoral districts are urban areas whose segmentation and community interests are certainly different from the other electoral districts. Interview with Adlin Omar:

"If it can be said that the electoral region 3 is quite well established because the area is in office and trade centers, maybe Medan Helveti is a densely populated population, especially in my home area. The community feels more individualistic because there are many economically well-established people" Yusri Tambunan, October 2015)

Referring to Adlin Omar's statement, there were difficulties he experienced in interacting with the community in electoral district 3 due to the individualistic attitude towards the community. This is possible because economically the people in this area are considered quite well established, so the need for economic access is not a top priority. Next Adlin also said:

"I want to focus more on developing the resources that young people have. Maybe also because my background as an entrepreneur and I am still young, I want to be involved in building a creative economy that can be an economic resource for young people, so that the younger generation is not only focused on finding formal employment. " (Interview with Adlin Omar Yusri Tambunan, October 2015)

Referring to the interview above, it seems that being a member of the Medan City DPRD, Adlin Omar Yusri Tambunan has hopes that he can contribute to fighting for his ideas in building resources in the city of Medan. His desire to develop the potential of young people in building creative businesses is part of his orientation to compete in the 2014 elections yesterday. As a people's representative from a youth group, there is an identity that remains to be raised by Adlin Omar Yusri Tambunan when it appears from his desire to build the economy of the young generation by 
encouraging youth groups to become entrepreneurs.

Related to what efforts Adlin Omar must do to realize his ideas, can be seen from the following interview:

"The ease of licensing matters is one of the factors so that community business activities can develop, so I want to encourage the existence of regulations that enable the community to easily manage business licensing as well as being a source of Medan's PAD." (Interview with Adlin Omar Yusri Tambunan, October 2015)

In addition, his desire to become a member of the DPRD was also based on the desire of Adlin Omar Yusri Tambunan to be directly involved and supervise the implementation of government in the city of Medan. Adlin Omar hopes that there will be major improvements to infrastructure in the city of Medan which are still considered lacking, considering that Medan is one of the largest cities in Indonesia and is the capital of the province of North Sumatra. This was confirmed by Adlin Omar in the following interview:

"Before sitting as a member of the Medan DPRD, I also thought that if later elected, I would seriously guard the administration of the city in Medan. Budget use must be effective, because the legislative function is one of supervision, "(Interview with Adlin Omar Yusri Tambunan, October 2015)

Next Adlin also said: "....... and because there is also a function of the budget, so in the APBD I also want to fight for a large budget for infrastructure improvements. If we look at it, there are still many roads in Medan that are damaged, not to mention the rainy season which often causes flooding until the street lighting at night is also not evenly distributed "(Interview with Adlin Omar Yusri Tambunan, October 2015)

From the interview described above, it was not without reason then Adlin Omar Yusri Tambunan plunged into the world of politics and competed in the 2014 legislative elections ago and was elected as a member of the Medan City DPRD at a young age. The election of Adlin Omar as a member of the Medan City DPRD with his view or orientation towards the construction of the city of Medan should be realized by Adlin Omar Yusri Tambunan. Responsibility as a people's representative with a moral burden as a young politician accompanied by the values inherent in a young man makes Adlin's figure required to carry out his main duties and functions as a member of the Medan DPRD properly.

Likewise, Ibnu Ubayd Dilla who was a member of the Regional Representative Council of Medan at the age of not even 26 years is the youngest member of Medan DPRD at this time. As a young politician, of course Ibnu Ubayd Dilla does not have the experience of becoming a representative of the people of Medan city. But the election of Ibn Ubayd Dilla to become a member of the DPRD certainly gave rise to a huge demand for this young politician to play a greater role in carrying out the main tasks and functions of the institution inherent in him.

The orientation of being a member of the Medan DPRD was stated by Ibnu Ubayd Dilla in the interview as follows:

"I don't have much organizational experience, my interest in participating in 
the legislative elections in Medan was initially because there was an urge to be able to do more with the community. I am a native of Medan who was born and raised here, so there is a feeling of my moral responsibility to serve the community, well one of them may be through the Medan DPRD I can do it for the people "(Interview with Ibnu Ubayd Dilla, November 2015).

As a native of Medan, Ibnu Ubayd Dilla felt that there was a role to play in the midst of society. The role of being a representative of the people is a fairly rational choice of roles for these young politicians to fight for. Regarding its orientation towards the development of the city of Medan, Ibnu Ubayd Dilla said:

"I think the young man is an energetic person, and I am still quite young so there are many things that cross my mind to participate in developing the city of terrain. The thing I thought about at the beginning when I became a legislative candidate from electoral area 5 was the improvement of infrastructure there. Maybe we both know that the northern Medan region is an area that is still behind compared to the more advanced southern Medan area. I want to fight for how the direction of development in Medan has begun to be focused in the North Medan area. This is the aim to provide economic equality to the community if development in the North Medan area is good "(Interview with Ibnu Ubayd Dilla, November 2015).

The interview quote above shows that as a representative of the people, Ibnu Ubayd Dilla had thought from the start he was nominated in the electoral district 5 to win the competition and become a representative of the people so that his desire to contribute to building the city of Medan, especially the electoral region 5 could be fought. Regional infrastructure improvements in North Medan have become one of the focuses of Ibnu Ubayd Dilla to fight for as a member of the Medan City DPRD. With regard to more significant things to be done by Ibnu Ubayd Dilla he explained in the following interview:

"I will encourage people in District 5 to conduct population administration such as KTP, KK, and birth certificates, so that all people in District 5 will later be recorded in the population system, so I want to recommend to simplify the affairs of population administration which may still be considered sufficient difficult to access by the community "(Interview with Ibnu Ubayd Dilla, November 2015)

From the results of the interview described above, the figure of young politician Ibnu Ubayd Dilla also has an orientation in the construction of the city of Medan. Not just being a member of the Medan City DPRD, Ibnu Ubayd Dilla turned out to have a development view in his efforts to participate in the 2014 legislative elections. The realization of the development orientation possessed by Ibn Ubayd Dilla is certainly something that the public awaits. Idealism as a young person became the hope of the people that must be maintained by Ibn Ubayd Dilla in the midst of the high culture of corruption and pragmatics that plague the nation today.

These two young politicians certainly have a moral responsibility to continue fighting for the values inherent in the youth. The presence of both of 
them as part of the current state administrators is required to be able to provide a glimmer of hope to the people who are increasingly apathetic and skeptical of their government. As an illustration of how young people are part of the history of nation and state development, it is hoped that these two young politicians will be able to answer the challenges they have as representatives of the community, especially in Medan City.

\section{CONCLUSION}

The young politicians who participated in the legislative candidates for the city of Medan in 2014 were young politicians who managed to penetrate the practical political barrier among the views of the dominance of senior politicians. The ability of the two young politicians who managed to sit as representatives of the people was inseparable from their ability to compete in the 2014 legislative elections.

Political Capital is a very important factor in political contestation. The existence of political vehicles in the form of bearer political parties is a must for someone to compete in the legislative elections. Even social capital actually has a significant influence on the winning process. But this capital is not too important considering that young politicians who have not taken root in society are able to be elected as legislators. Economic capital seems to be the most decisive factor in political contestation. The ability to have strong economic capital can create other political capital.

The involvement of young politicians in the legislative elections gave birth to the paradigm that politics which is generally dominated by senior politicians can also be carried out by youth groups, so that this creates a political development in which the democratic system can grow well.

\section{BIBLIOGRAPHY}

Djojosoekarto, A. \& S, Utama. (2008). Democratic Transformation of Political Parties in Indonesia. Jakarta: Partnership

Wibawanto, A. (2006). Strategy for Winning Elections - Winning People's Hearts and Thoughts. Yogyakarta: Pondok Edukasi. Moertopo, A. (1974). National Political Strategy. Jakarta: CSIS.

Firmanzah. (2007). Political Marketing. Jakarta: Torch.

Nanawi, H. (1992). Research Instrument in the Social Sector. Yogyakarta: Gadjah Mada University Press.

Friedman, L.M. \& Ali, A. (2002). Revealing the Veil of Law. Jakarta: Mount Agung.

Moleong \& Lexy, J. (2007). Qualitative Research Methodology. Bandung: PT Adolescent Rosdakarya Offset.

Miles, M. \& Huberman, M. (1992). Qualitative data analysis. Jakarta: IU Press.

Nazir, M. (1988). Research methods. Ghalia Indonesia.

Deddy, M. (2004). Qualitative Research Methodology. Bandung: PT Remaja Rosdakarya. 
Nasution. (2003). Research Methods: Scientific Research, Jakarta: PT. Earth Literacy.

Gajah Mada University Press.

Sukmadinata. (2005). Educational Research Methods. (Bandung:

Schroder, P. (2004). Political Strategy. Jakarta: Friedrich Naumann Stiftung. Teenager Rosdakarya.

International Idea (translation), Women in Parliament: Not Just Amount

Pujosuwarno, S. (1992). Practical Instructions for Counseling. Yogyakarta: Menara Mas Offset. from (AMMEEPRO; Jakarta, 2002)

http://id.wikipedia.org/wiki/Komisi

Sukandarrumidi. (2002). Research _Pemilihan_Umum Methodology Practical Instructions for Beginner Researchers. Yogyakarta: 